\title{
Work-Life Balance Practices and Demographic Influence: an Empirical approach
}

\author{
Lavanya L, Dr. N. Thangavel \\ Research Scholar, Dravidian University, Kuppam and Asst. Prof., NIMS,Chennai. \\ Principal (PG), Jeppiaar Engineering College, Chennai.
}

\begin{abstract}
The topic of Work-Life balance is a much researched arena, still, the scope of research in this area is amazing. The present article is also under the ambit of Work-life balance, but the researcher focuses on the Work-Life Balance Practices (WLBPs) provided in organisations. The primary objective of the study is identify the impact of demographic factors in taking-up of WLBPs in an IT companies. For the scope of the study, the sample population is set to be women employees working in IT companies in Chennai. A questionnaire was constructed for the research and through online forms and emails questionnaire was distributed. By using Convenience sampling method, 273 responses were collected and analysed using Factor Analysis and Multiple Regression. The results of the analysis indicate that for certain practices there is a definite impact based on the demographic profile of the respondents. The limitation of the study is that it is set to top IT companies (based on Dataquest list 2010) in Chennai and may not be generalised for other industries or SME sector. The practical implication would be for the HR Managers in IT sector, to address their current WLBPs in view of the results of this study.
\end{abstract}

Key Words: Work-Life Balance Practices (WLBPs), Women Employees, IT companies, Demographic Factors

\section{Introduction and Background of the Study:}

The amazing scope of Work-life balance has fascinated many researchers into this stream of research. The present paper is also on the theme of Work-life balance and focuses on the Work-Life Balance Practices offered in organisations. The IT industry has been a pioneer in bringing out innovative HR policies relating to Work-Life Balance for its employees. The practices have helped breathe easy for many of the employees and in particular, women employees, who have the major responsibility to juggle their personal and professional lives and are bound by their domestic responsibilities (Kalghatgi and Seth (2003), Statistics Cananda (2001), Juliana et al (2006)). Also, a survey conducted by Centre for Work-Life Policy (2001), pointed out that fully $40 \%$ of highly qualified women with spouses felt that their husbands create more work around the house than they perform. It brings out that women need to have more strategies in place to balance their work and life and organisations should bring out policies to support them.

Organisations also lend a helping hand in the form of Work-Life Balance Practices (WLBPs) to attract, retain their women employees and help them move upwards in their career. Earlier studies have brought out the advantage of having WLBPs in companies. Crompton and Le Feuvre (1992) report that during the 1980s new career break schemes were introduced to encourage women to retain their links with banking work and it is now one of the largest private sector providers of Child care in Britain. Comfort et al (2003) analysed the data collected from new Workplace and Employee Survey (WES) and showed that only 2 to $7 \%$ of workers analysed reported having child or elder care services available to them at the workplace. Also, women reported lower flexitime participation rate than men; $44 \%$ of men reported a flextime arrangement, as compared to only $36 \%$ of women. Van Daalen, Willemsen, Sanders (2006) show in their research that women tend to derive less benefit from social support from their supervisors/colleagues in comparison to their male counterparts.

These studies reveal that gender based studies on utilisation of WLBPs have been taken up by various researchers. This sets the background for this study, whether, any demographic profile, apart from Gender influences employees to make use of the Work-Life Balance Practices available in their organisations.

\section{Review of Literature and Research Gap:}

Any research begins with the understanding of the existing literature. Some of the literature studied in the present background are highlighted below.

In a study on Perceptions of nonwork-to-work spill over: Challenging the common view of conflictridden domain relationships, Kirchmeyer (1992) brought out that employees in the same organisation for a longer period of time, tend to make use of the WLBPs available in the company to take of their non-work commitments. Frone and Yardley (1996) suggested that the age of the youngest child of the employee influenced the use of policies like flexitime and compressed work week. Also, the number of dependants influenced the use of child care facilities. 
Allen (2001) suggested that though age differences do not impact the use of WLBPs, the choice of the practice differs with age. Older employees are found to use many dependant care policies like Childcare, Elder care, Paid Maternity leave and the like. The study also suggested that married employees are more likely to use these policies compared to unmarried employees.

DiNatale \& Boraas (2002) 25 to 34 year old women are more likely than women of other ages to opt for flexibility in their jobs. This is possibly attributed to the responsibilities associated with dependant care in this age group as women need time for the young ones at home. Though Child care facilities are available, women still depend on friends and family rather than paid-help to take care of their kids. This is studied in a research by Susan Halford, Mike Savage and Anne Witz (1997) in Banking, Local Government and Nursing Sectors.

Fisher and Layte (2003) bring out three distinct sets of measures of work-life balance: proportion of free time, the overlap of work and other dimensions of life, and the time spent with

other people. The variables such as the age, gender, life-cycle stage, ethnicity, citizenship, and childcare arrangements also play a significant role in the measures of Work-Life Balance of Employees (Wallace and Cousins 2004).

In a study of employees in a Government Department in New Zealand, on the factors affecting the employee use of Work-Life Balance Intiatives, using Correlation and Multiple Regression, it was identified that the age was not significant in the usage of WLBPs. The other demographic factors like Number of dependants and Marital status were also not found to be influencing the use of WLBPs. Whereas, tenure of the employee in an organisation had an influence on the usage of the initiatives (Smith J and Gardner D, 2007).

Rana Zehra Masood, Seema Mahlawat (2012) studied the impact of Gender, Experience, Level of Management in the critical factors of Work-Life Balance practices in the Private and Public Banks and Insurance Companies in Haryana. The study showed Employer Critical Factors and Organisational Critical Factors in usage of WLBPs. Using a non-probability stratified samples of 300 employees, by using ANOVA, the researcher found that the demographic factors under study influence the critical factors of WLBPs like employees having 18-23 years experience took time-off for family support and study leave or training leave. With regard to Gender, women dominated in the usage of Spontaneous Off, Religious leaves and LTC. Most of the lower level employees, opted for Emergency Leave and Paid Maternity Leave.

The review of literature brings out that studies on demographic factors influence on use of WLBPs have been taken up in different sectors. The Indian IT, surprisingly, have not been under much research in the literatures reviewed. The present study takes up the gap and focuses on the IT sector in Chennai, Tamil Nadu.

\section{Objectives:}

The Primary objective of the study is to identify the impact of demographic factors in the take-up of Work-Life Balance Practices.

\section{Operational Definitions:}

1.The Demographic Factors mentioned in the article refers to the Age, Level of Management, Experience, Experience in Present Organisation, Education, Type of Family, Number of Dependants, Annual Income and Marital Status.

2. The Work-Life Balance Practices are also termed as Work-Life Balance Initiatives, Work-Life Balance Programs and Family-Friendly Policies in the study based on the literature studied.

3. Take-up refers to the availing or utilisation or usage of WLBPs in an organisation.

\section{Methodology:}

To meet the objective of the study, a questionnaire was constructed bringing out the popular WLBPs based on availability of such practices in Indian companies as brought out by Boston College Executive Briefing Series (by Ujvala Rajadhyaksha, 2009) and NHRD Journal article (by V Chandra and CS Venkata Ratnam, 2009). The study is limited to women working in top IT companies (based on Dataquest survey 2010) in Chennai. The questionnaire was mailed to women employees in IT companies in Chennai and online forms (Google Forms) was also used for data collection. The study is descriptive in nature and by using convenience sampling, 273 samples were collected. The data collected was analysed using SPSS v.20 for Factor Analysis and Multiple Regression.

\section{Reliability Test:}

The reliability of the questionnaire was checked through Cronbach Alpha value in SPSS 20, which showed a value of $81.4 \%$ making the questionnaire reliable to conduct the study. 


\section{Demographic Profile:}

\section{Analysis and Discussion:}

The frequency table shows that $46.5 \%$ of women belong to Middle level Management and majority of the respondents are in the age group of 26 - 35 years (45.1\%). Only $7 \%$ of the respondents are with above 15 years experience and majority are with 3 to 5 years experience. 52\% of the respondents were with less than 3 years experience in the same company. More than half of the respondents (52.4\%) were Postgraduates working in IT companies. $71.1 \%$ of the women employees surveyed, were leading a Nuclear family. Also, 29.3\% of employees have 1 to 2 dependants to support. $33.7 \%$ of the respondents had an annual income of 3 to 5 lakhs and $51.6 \%$ of the respondents were married.

This provides an overview of the varied type of respondents' profile who took up the study. The next analysis focuses on reduction of variables used for the study using Factor Analysis.

\section{Formation of Factors:}

The researcher has used Factor Analysis to understand the variables falling into groups so that variables with common characteristics can be studied together by further analyses.

Table 1 KMO and Bartlett's Test

\begin{tabular}{|c|c|c|}
\hline \multicolumn{3}{|c|}{ Kaiser-Meyer-Olkin Measure of Sampling Adequacy. } \\
\hline \multirow[t]{2}{*}{ Bartlett's Test of Sphericity } & df & 55 \\
\hline & Sig. & .000 \\
\hline
\end{tabular}

Source: Primary Data

With Kaiser-Meyer-Olkin measure of sampling adequacy, it is found that the value is 0.761 and Bartlett's test of Sphericity's approximate Chi-Square value is 936.929 and is statistically significant at 5\% level. This indicates that the sample size is adequate to reduce 11 variables into predominant factors. The Bartlett's Test of Sphericity indicates that the distribution is normal to group the variables into suitable factors.

From the communality table (Table 2) it is found that the variance ranges from .343 to .749 and can be reduced to factors. Eigen values 3.527 and 2.087 indicate that 2 factors are formed showing individual variances of 29.283 and 21.753 . The cumulative variance shows $51.036 \%$ which is more than the desired $40 \%$ variance. Therefore, it confirms the formation of 2 meaningful factors.

Table 2 Communalities

\begin{tabular}{|c|c|c|}
\hline & Initial & Extraction \\
\hline W1 & 1.000 & .623 \\
\hline W2 & 1.000 & .749 \\
\hline W3 & 1.000 & .397 \\
\hline W4 & 1.000 & .500 \\
\hline W5 & 1.000 & .343 \\
\hline W6 & 1.000 & .537 \\
\hline W7 & 1.000 & .548 \\
\hline W8 & 1.000 & .539 \\
\hline W9 & 1.000 & .599 \\
\hline W10 & 1.000 & .428 \\
\hline W11 & 1.000 & .351 \\
\hline
\end{tabular}

Extraction Method: Principal Component Analysis

W1 to W11 refers to statement numbers in the questionnaire

Source: Primary Data

From the Rotated Component Matrix Table (Table 3), Factor 1 consists of the following questionnaire statements -

\begin{tabular}{|l|l|}
\hline W2. Part-time work arrangement is used by many working mothers. & 0.862 \\
\hline W1. Flexible Working Arrangement is a highly used option in company. & 0.784 \\
\hline W4. Crèche facilities are utilized to the maximum in the company. & 0.688 \\
\hline W3. Shift changes for needed occasions are availed by women employees. & 0.574 \\
\hline
\end{tabular}

W1 to W11 refers to statement numbers in the questionnaire

The variables above primarily indicate the practices relating to time flexibility in the work schedule. Since, majority of the policies relate to flexibility, this factor is termed as "Flexible Work Practices." 


\begin{tabular}{|c|c|c|}
\hline & \multicolumn{2}{|c|}{ Component } \\
\hline & 1 & 2 \\
\hline W2 & & .862 \\
\hline W1 & & .784 \\
\hline W9 & .761 & \\
\hline W7 & .729 & \\
\hline W8 & .721 & \\
\hline W6 & .715 & \\
\hline W4 & & .688 \\
\hline W10 & .643 & \\
\hline W11 & .588 & \\
\hline W3 & & .574 \\
\hline W5 & .460 & \\
\hline
\end{tabular}

Extraction Method: Principal Component Analysis.

Rotation Method: Varimax with Kaiser Normalization.

a. Rotation converged in 3 iterations.

W1 to W11 refers to statement numbers in the questionnaire

Source: Primary Data

The second Factor from the table (Table 3) is listed as below -

\begin{tabular}{|l|l|}
\hline W9. Mentor - Mentee relationships are very common in the company. & 0.761 \\
\hline $\begin{array}{l}\text { W7. Technical training programs hones skills and therefore, women employees grab when the opportunity is given by the } \\
\text { company. }\end{array}$ & 0.729 \\
\hline W8. Getting to meetings of professional bodies is not missed by women employees. & 0.721 \\
\hline W6. Women employees attending training program (health awareness or related) is a routine in the company. & 0.715 \\
\hline W10. Complaining of instances of Sexual Harassment has not been a hindrance to progress in the organization. & 0.643 \\
\hline W11. Sabbaticals are used based on necessity by women employees. & 0.588 \\
\hline W5. Women come back in to their same role (job) after Maternity Leave without any issues. & 0.460 \\
\hline
\end{tabular}

W5. Women come back in to their same role (job) after Maternity Leave without any issues.

$\mathrm{W} 1$ to $\mathrm{W} 11$ refers to statement numbers in the questionnaire

The above variables primarily relate career development of an employee through training, mentoring, women-supportive practices like welcoming after Maternity break and Sabbaticals and support against sexual harassment of an employee. These practices would help employee move up the career ladder. Hence, these practices are named as "Career Development Practices."

By using Exploratory Factor Analysis, formation of two factors - Flexible Work Practices and Career Development Practices have been arrived at. In the next section, the researcher identifies whether the demographic factors influence the usage of these practices in an organisation. For this, Multiple Regression is applied.

\section{Impact of Demographic Factors on Take-up of WLBPs:}

From the above section, the take-up of WLBPs have been formed in to two groups, namely, Flexible Work Practices and Career Development Practices. The impact of demographic factors on each of these is tested below using Multiple Regression.

Ho(a): The demographic factors does not impact the usage of Flexible Work Practices(FWP).

Table 4 Model Summary ${ }^{\mathrm{b}}$

\begin{tabular}{|l|r|r|r|r|r|}
\hline Model & \multicolumn{1}{|c|}{$\mathrm{R}$} & R Square & Adjusted R Square & $\begin{array}{c}\text { Std. Error of the } \\
\text { Estimate }\end{array}$ & Durbin-Watson \\
\hline 1 & $.348^{\mathrm{a}}$ & .121 & .091 & .77235 & 1.191 \\
\hline
\end{tabular}

a. Predictors: (Constant), Maritalstatus, Typeoffamily, Education, Dependents, Exppresent, Levelofmgmt,

Annualincome, Age, Experience

b. Dependent Variable: FWP 
From the above table it is found that $\mathrm{R}$ square value is .121 and Durbin-Watson statistics 1.191 indicates that the demographic factors bring out $12.1 \%$ variations in the Flexible Work Practices in organisations.

The Significance and Goodness of Fit of Regression is verified in the following ANOVA table

Table 5 ANOVA $^{\mathrm{a}}$

\begin{tabular}{|rl|r|r|r|r|r|}
\hline Model & & Sum of Squares & df & Mean Square & F & Sig. \\
\hline \multirow{2}{*}{1} & Regression & 21.624 & 9 & 2.403 & 4.028 & $.000^{\mathrm{b}}$ \\
& Residual & 156.884 & 263 & .597 & & \\
& Total & 178.509 & 272 & & & \\
\hline
\end{tabular}

a. Dependent Variable: FWP

b. Predictors: (Constant), Maritalstatus, Typeoffamily, Education, Dependents, Exppresent, Levelofmgmt,

Annualincome, Age, Experience

From the above table it is found that $\mathrm{F}=4.028, \mathrm{p}=.000$ are statistically significant at $5 \%$ level. This concludes that the independant variables of demographic factors are more appropriate in creating influence over Flexible Work Practices in the organisations.

Therefore, at this point, it is important to sharply estimate the individual influence of the demographic factors on Flexible Work Practices.

Table 6 Coefficients ${ }^{\mathrm{a}}$

\begin{tabular}{|c|c|c|c|c|c|c|}
\hline \multicolumn{2}{|c|}{ Model } & \multicolumn{2}{|c|}{ Unstandardized Coefficients } & \multirow{2}{*}{$\begin{array}{c}\begin{array}{c}\text { Standardized } \\
\text { Coefficients }\end{array} \\
\text { Beta }\end{array}$} & \multirow[t]{2}{*}{$\mathrm{t}$} & \multirow[t]{2}{*}{ Sig. } \\
\hline & & $\mathrm{B}$ & Std. Error & & & \\
\hline \multirow{10}{*}{1} & (Constant) & 3.320 & .306 & & 10.841 & .000 \\
\hline & Levelofmgmt & .255 & .088 & .205 & 2.891 & .004 \\
\hline & Age & .049 & .132 & .041 & .374 & .709 \\
\hline & Experience & -.045 & .116 & -.048 & -.388 & .698 \\
\hline & Exppresent & -.054 & .111 & -.043 & -.482 & .630 \\
\hline & Education & -.102 & .100 & -.065 & -1.022 & .308 \\
\hline & Typeoffamily & .108 & .110 & .061 & .980 & .328 \\
\hline & Dependents & .100 & .066 & .099 & 1.523 & .129 \\
\hline & Annualincome & -.299 & .088 & -.315 & -3.404 & .001 \\
\hline & Maritalstatus & -.048 & .060 & -.050 & -.799 & .425 \\
\hline
\end{tabular}

a. Dependent Variable: FWP

From the above table, it is found that, Level of Management ( $\mathrm{t}=2.891, \mathrm{p}=.004)$ is statistically significant at 5\% level. This shows that the differing levels of management use the WLBPs variedly. This is also highlighted in other studies where the entry level employees opted for flexitime practices compared to Senior Level employees (Comfort, Johnson and Wallace, 2003).

It is also found that Annual Income $(t=-3.404, p=.001)$ is statistically significant at $5 \%$ level. This shows that annual income of an employee has an impact in the take-up of flexitime practices provided in the organisation. Since, $t$ value is negative, we can conclude that the women employees perceive a negative impact in usage of WLBPs related to flexible timings based on the income of the employee. This could be because of differing priorities of women employees at different income level, as for example, a survey by MMA among working women in Chennai shows that the higher income group (10+ lakhs per annum) dedicate time for professional reading, certifications and getting trained and also attend as many professional events as possible (Sivagami and Nithya, 2010).

Hence, we can reject the null hypothesis Ho (a) and state that demographic factors of Level of Management and Annual Income impact the usage of Flexible Work Practices.

Ho(b): The demographic factors does not impact the usage of Career Development Practices(CDP).

Table 7 Model Summary ${ }^{\mathrm{b}}$

\begin{tabular}{|l|r|r|r|r|r|}
\hline Model & \multicolumn{1}{|c|}{$\mathrm{R}$} & R Square & Adjusted R Square & $\begin{array}{c}\text { Std. Error of the } \\
\text { Estimate }\end{array}$ & Durbin-Watson \\
\hline 1 & $.417^{\mathrm{a}}$ & .174 & .145 & .52461 & 1.628 \\
\hline
\end{tabular}

a. Predictors: (Constant), Maritalstatus, Typeoffamily, Education, Dependents, Exppresent, Levelofmgmt,

Annualincome, Age, Experience

b. Dependent Variable: CDP 
Work-Life Balance Practices and Demographic Influence: an Empirical approach

\begin{tabular}{|c|c|c|c|c|c|c|}
\hline & & Sum of Squares & df & Mean Square & $\mathrm{F}$ & Sig. \\
\hline \multirow{3}{*}{1} & Regression & 15.198 & 9 & 1.689 & 6.136 & $.000^{\mathrm{b}}$ \\
\hline & Residual & 72.381 & 263 & .275 & & \\
\hline & Total & 87.579 & 272 & & & \\
\hline
\end{tabular}

From the above table (Table 7) it is found that $\mathrm{R}$ square value is .174 and Durbin-Watson statistics 1.628 indicates that the demographic factors bring out $17.4 \%$ variations in the Career Development Practices in companies.

The Significance and Goodness of Fit of Regression is verified from the ANOVA table (Table 8). It is found that $\mathrm{F}=6.136, \mathrm{p}=.000$ are statistically significant at $5 \%$ level. This concludes that the independant variables of demographic factors are more appropriate in creating influence over the Career Development Practices in organisations.

Therefore, at this point, it is important to sharply estimate the individual influence of the demographic factors on Flexible Work Practices.

Table 9 Coefficients ${ }^{\mathrm{a}}$

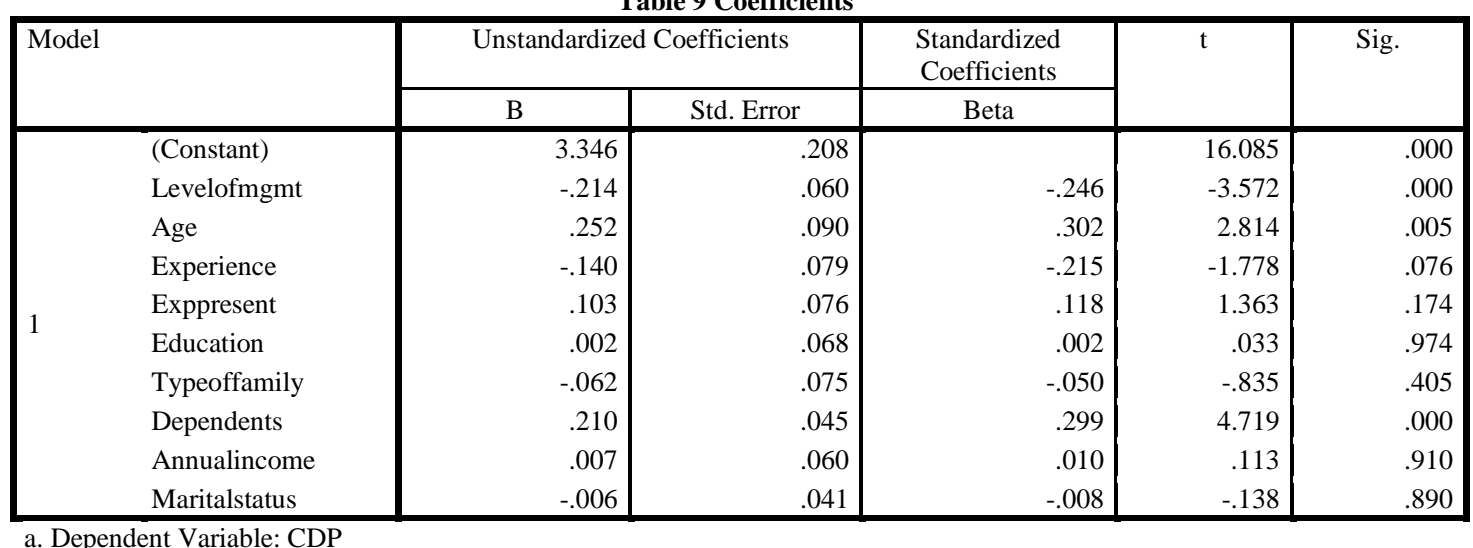

From the above table, it is clear that Level of Management $(\mathrm{t}=-3.572, \mathrm{p}=.000)$, Age $(\mathrm{t}=2.814, \mathrm{p}=.005)$, Number of Dependents $(\mathrm{t}=4.719, \mathrm{p}=.000)$ are statistically significant at $5 \%$ level. It indicates that usage of Career Development Practices varies with Level of Management. This is shown in another research study where it is reported that employees in the Senior level are not able to make use of the WLBPs available in the organisation (Liz Doherty 2004). Since, $t$ value is negative for level of management, it can be pointed out that, women employees in the study perceive a negative impact of level of management in take-up of Career Development Practices.

Also, age of the employee brings out difference in the take-up of Career Development Practices. The Number of dependents for an employee is also significant. The study in Newzeland Government department brought out that there is no impact of the number of dependants on usage of WLBPs (Smith J and Gardner D, 2007). But, in this study, it is clearly evident that number of dependents influence the usage of WLBPs with respect to Career Development Practices like attending training programs, professional networking and meetings and making use of Mentoring programs.

Therefore, we can conclude the regression analysis by rejecting the null hypothesis Ho(b) and accepting that certain demographic factors like Level of Management, Age and Number of Dependents influence the use of WLBPs related to Career Development Practices.

\section{Findings and Suggestions:}

The analysis and discussions have highlighted the following findings in the study -

(a) The customary demographic study showed that $46.5 \%$ of women belong to Middle level Management, $71.1 \%$ of the women employees surveyed, were leading a Nuclear family. Also, 29.3\% of employees have 1 to 2 dependants to support. $33.7 \%$ of the respondents had an annual income of 3 to 5 lakhs and $51.6 \%$ of the respondents were married.

(b) Factor Analysis brought out formation of two categories of Practices - Flexible Work Practices and Career Development Practices. 
(c) With regresssion, it was found that Level of Management and Annual Income influence the take up of Flexible Work Practices.

(d) It is also found that Level of Management, Age and Number of Dependents influence the use of WLBPs related to Career Development Practices.

The Suggestions which are the Practical Implications of the Study are as below -

(a) The differing age groups have different career orientation policy requirement as understood from the study. The companies can design their WLBPs according to the age profile of their employees, as there tends to be varying priority for the different age groups in the study.

(b) The number of dependants for an employee influences the women employee to opt for certain practices like Child Care or Elder Care Practices. The provision of the same in the company would help women with dependants.

(c) The Career Development Practices (CDPs) are influenced by number of dependants for a women employee. So, the HR manager should understand the profile of the employees in implementation of the WLBPs.

(d) As Annual Income influences Flexible Work Practices (FWPs), it is suggested that the type of policies used by differing income group be offered accordingly to benefit the employees.

(d) The accessibility of the Work-Life Balance policies to all the employees is essential as there is difference in usage of policies at different levels of management. Since Level of Management is an influential factor, organisations can create conducive atmosphere for the WLBPs to be available to all.

(e) As evident from the study, level of management influences both Career Development Practices (CDPs) and Flexible Work Practices (FWPs). So, it is necessary that the CDPs and FWPs are designed to suit the needs to employees at different levels in the organisation.

\section{Limitations and Directions for Further Research:}

The limitations of the study are that the study focuses on top companies in Chennai in IT sector and for women employees working in those companies. The future studies can be extended to other companies in the same industry to facilitate comparison the usage of practices in top companies vis-a-vis other companies in the same sector.

\section{Conclusion:}

Work-Life Balance Practices are of value to all with more importance to women, give their dual responsibility at work and home. A recent Chennai roundtable brought out that Flexi working should be made available in all organisations as a compulsory policy, to facilitate women employees take care of their personal responsibility and also, enhance their professional life. The policies such as these, if made mandatory would benefit the employees at large and help in the retention of women employees. Many IT companies have pioneered innovative policies with the recent being Accenture's Leave pooling policy. The other companies should work out on the model feasible for them and drive their company towards engaged workforce, which, in turn would create a successful organisation.

1. WLBPs - Work-Life Balance Practices

\section{Abbreviations Used:}

2. CDP - Career Development Practices

3. FWP - Flexible Work Practices

\section{References:}

[1]. Allen (2001), "Family-Supportive Work environments: the role of organisational perceptions," Journal of Vocational Behaviour, 58(3) 414-435

[2]. Comfort Derrick, Johnson, Karen and Wallace, David (2003) "Part-time work and family friendly practices in Canadian workplaces" The Evolving Workplace Series, Statistics Canada. http://www.statcan.ca/english/freepub/71-584-MIE/free.htm

[3]. Centre for Work-Life Policy (2001), As mentioned in "Off-Ramps and On-Ramps - Keeping talented women on the road to success," Sylvia Ann Hewlett and Carolyn Buck Luce, Harvard Business Review on Women in Business, Harvard Business School Publishing Corporation 2005

[4]. Crompton and Le Feuvre (1992), Gender, Careers and Organisations, Susan Halford, Mike Savage and Anne Witz, Mac Millan Press Ltd., 1997 Pp 202

[5]. Dataquest (2010), survey available at http://dqindia.ciol.com/content/dqtop20_10/CompanyRanking/2010/210072302.asp retrieved 21.03.2011

[6]. DiNatale, M., \& Boraas, S. (2002), "The labor force experience of women from 'generation X', " Monthly Labor Review, 125(3), 315.

[7]. Fisher, K., and M. Layte (2002-2003), "Measuring work-life balance and degrees of sociability: A focus on the value of time use data in the assessment of quality of life." Working Paper of the European Panel Analysis Group 32.

[8]. Frone, M.R and Yardley, J.K. (1996), "Work place Family - Supportive Programmes: Predictors of employed parents' importance ratings," Journal of Occupational and Organisational Psychology, 69(4), 351-356

[9]. Jeniffer Smith and Deanne Gardner (2007), "Factors Affecting Employee Use of Work-Life Balance Initiatives," New Zealand Journal of Psychology, 36(1), March 2007 
[10]. Juliana et al (2006), Work - Life Balance: Review of Literature, C S Venkata Ratnam and V Chandra, NHRD Network Journal, July 2009 Vol. 2 Issue 3

[11]. Kalghatgi and Seth (2003), "Why just a few women on top?," Dataquest, 30 June, retrieved from http://www.dqindia.com/content/strategy/hrd/103063001.asp

[12]. Kirchmeyer C (1992), "Perceptions of nonwork-to-work spill over: Challenging the common view of conflict-ridden domain relationships," Basic and Applied Social Psychology, 13(2),231-249

[13]. Liz Doherty, (2004) "Work-life balance initiatives: implications for women", Employee Relations, Vol. 26 Iss: 4, pp.433 - 452

[14]. Rana Zehra Masood, Seema Mahlawat (2012), "Impact of Demographic Variables on the Critical factors of Work-Life Balance: An Empirical Study", Journal of Organisational Management, 1(1), 01-13, 2012

[15]. Sivakami Suryanarayanan and Nithya Venkataraman (2010), "MMA-Cerebrus Survey of working women in Chennai," MMACerebrus survey, Business Mandate, March 2010, 37(8),3-7.

[16]. Statistics Canada (2001) as reported in "Issues and Prospects relating to Work-Life Balance," Harish C Jain, NHRD Network Journal, July 2009 Vol.2 Issue 3 Work-Life Balance

[17]. Susan Halford, Mike Savage and Anne Witz (1997), "Gender, Careers and Organisations," Mac Millan Press Ltd., 1997 Pgs 2 to 14

[18]. Ujvala Rajadhyaksha (2009), "Work-life in India", Boston College Center for Work \& Family Executive Briefing Series, pp 8

[19]. V Chandra and C S Venkata Ratnam (2009), "Model Guidelines and Best Practices for Family Friendly Workplaces and Workforce," Work Life Balance, NHRD Network Journal, Volume 2, Issue 3, July 2009, pp 84 - 86

[20]. Van Daalen, G., Willemsen, T. M., \& Sanders, K. (2006). Reducing work-family conflict through different sources of social support. Journal of Vocational Behavior, 69, 462-476. http://www.hwf.at/downloads/open_area/publications/forum_publications_04.pdf.

2004 "Household
m_publications_04.pdf. 